\title{
Evaluation of the abuse liability of aminorex
}

\author{
W.L. Woolverton*a, B.W. Massey ${ }^{a}$, G. Winger ${ }^{b}$, G.A. Patrick ${ }^{c}$, L.S. Harris ${ }^{c}$ \\ ${ }^{a}$ Department of Psychiatry, University of Chicago, Chicago, IL, USA \\ ${ }^{b}$ Department of Pharmacology, University of Michigan, Ann Arbor, MI, USA \\ ${ }^{c}$ Department of Pharmacology and Toxicology, Virginia Commonwealth University, Medical College of Virginia, Richmond, VA, USA
}

Received 30 May 1994; accepted 8 August 1994

\begin{abstract}
Aminorex is a cyclic phenylisopropylamine that has been marketed as an anorectic. Despite obvious pharmacological similarities to the amphetamines, little is known about its liability for abuse. In the present study, one group of rhesus monkeys $(n=3)$ was prepared with intravenous catheters and allowed to self-administer either methohexital or saline in daily experimental sessions. When methohexital and saline self-administration were stable and clearly different, various doses of aminorex $(0.001-0.1$ $\mathrm{mg} / \mathrm{kg} /$ injection) were made available for self-administration. Aminorex maintained self-administration above that maintained by saline and slightly lower than that maintained by methohexital in all monkeys. The discriminative stimulus effects of aminorex were evaluated in rhesus monkeys trained to discriminate $d$-amphetamine $(n=3)$ or pentobarbital $(n=4)$ from saline. Aminorex substituted completely for $d$-amphetamine as a discriminative stimulus but engendered little or no pentobarbital-appropriate responding. Aminorex stimulated locomotor activity in mice and exacerbated the withdrawal syndrome in rats that were dependent upon pentobarbital. These findings indicate that aminorex is a psychomotor stimulant that would be predicted to have significant $d$ amphetamine-like abuse liability in humans.
\end{abstract}

Keywords: Abuse liability; Rhesus monkey; Self-administration; Drug discrimination

\section{Introduction}

Aminorex (Fig. 1) is a cyclic phenylisopropylamine that was first synthesized in the early 1960 s and marketed in Europe as an anorectic (Roszkwoski and Kelley, 1963). It has been reported to be at least as potent and efficacious as $d$-amphetamine (AMPH) as an anorectic in humans (Hadler, 1967, 1970; Wood and Owen, 1965). Aminorex also decreases food intake in animals (Roszkowski and Kelley, 1963) and, like the amphetamines, stimulates locomotor activity (Costa et al., 1971). Although little is known about the mechanism of action of aminorex, it has been reported to increase dopamine turnover in rat striatum with no effect on turnover of brain NE (Costa et al., 1971). In addition, aminorex has been reported to release 5-HT

\footnotetext{
* Corresponding author, Department of Psychiatry and Human Behavior, The University of Mississippi Medical Center, 2500 N. State Street, Jackson, MS 39216.
}

from platelets (Fristrom et al., 1977). It has been proposed (Fristrom et al., 1977) that this effect is the mechanism underlying the pulmonary hypertension that develops with aminorex and that played a significant role in its removal from the market (Follath et al., 1971; Mlczoch et al., 1980).

Despite its notable similarities to the amphetamines, little is known about the abuse liability of aminorex. Early studies with humans subjects reported side effects (e.g., insomnia, jitteriness) that were similar to those found with the amphetamines (Hadler, 1967, 1970; Wood and Owen, 1965). However, subjective effects usually associated with abuse potential (e.g., euphoria) were not prominent in those reports. Aminorex has been recently found to substitute for AMPH as a discriminative stimulus in rats (Young, 1992), an effect usually associated with AMPH-like subjective effects in humans. Moreover, the aminorex derivative 4-methylaminorex has been reported to have behavioral effects in animals consistent with significant abuse liability 
Aminorex hydrochloride (4,5-Dihydro-5-phenyl-2-oxazolamine hydrochloride)

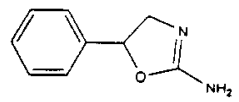

Fig. 1. Chemical structure of aminorex.

(Mansbach et al., 1990; Glennon et al., 1990) and has been found on the illicit market. Therefore, the purpose of the present study was to use animal models to assess further the abuse potential of aminorex. The compound was provided to the Drug Evaluation Committee of the College on Problems of Drug Dependence by the Drug Enforcement Administration. It was coded (CPDD 0039) and submitted blind to the testing laboratories (University of Chicago, University of Michigan, and Medical College of Virginia). The evaluations included reinforcing effects and discriminative stimulus effects in rhesus monkeys together with locomotor effects and effects on the pentobarbital abstinence syndrome in rodents.

\section{Methods}

\subsection{Reinforcing effects in rhesus monkeys}

The reinforcing effects of aminorex were evaluated in a substitution self-administration procedure with methohexital serving as the baseline drug. Four female rhesus monkeys weighing between 5.0 and $8.7 \mathrm{~kg}$ were surgically prepared with indwelling silicone rubber catheters using $10 \mathrm{mg} / \mathrm{kg}$ i.m. ketamine and $2.0 \mathrm{mg} / \mathrm{kg}$ i.m. xylazine as anesthetics. Catheters were implanted in jugular (internal or external), femoral or brachial veins as necessary. A catheter passed subcutaneously from the site of the incision to the mid-scapular region, where it exited the monkey and continued, through a hollow restraining arm, to the outside rear of the cage.

The restraint and catheter protection device has been described in detail by Deneau et al. (1969). Monkeys were individually housed in stainless steel cages, measuring $83.3 \times 76.2 \times 91.4 \mathrm{~cm}$ deep. Each monkey wore a tubular stainless steel harness that protected the exit site of the catheter and allowed relatively unrestricted movements within the cage. A Teflon cloth jacket (Alice King Chatham Medical Arts, Los Angeles, CA) provided further protection for animals who tended to locate and pull their catheters. The harness was connected to a flexible spring arm that carried the catheter to the back of the cage where it joined tubing passing through a roller infusion pump (Watson and Marlow Co., Model MHRK 55, Falmouth, UK).

A 15.4-cm square stimulus panel was located on the side of each cage, approximately $10 \mathrm{~cm}$ from the front and $19 \mathrm{~cm}$ from the bottom of the cage. Across the top of the stimulus panel, $2.5 \mathrm{~cm}$ apart, were three circles,
$2.5 \mathrm{~cm}$ in diameter, covered with translucent plastic and capable of being illuminated from behind by $5-\mathrm{W}$ colored bulbs. The two side lights could be illuminated red and the center light green. Below each of the two red stimulus lights there was a response lever (Model 12107; BRS-LVE, Beltsville, MD) capable of being operated by $10-15 \mathrm{~g}$ of force. Experimental control was provided by an IBM PS $/ 2$ computer programmed with Med-PC (Med-Associates, Fairfield, VT) software and located in an adjoining room.

Monkeys were adapted to restraining arms for a week or more, then an intravenous catheter was implanted and the animals were given the opportunity to press the response lever to receive drug injections. Evaluation of aminorex was carried out in monkeys that were allowed to self-administer sodium methohexital in baseline sessions. For these monkeys, at the beginning of each session, a red light was illuminated over one of two levers in each monkey's cage and ten responses (fixed-ratio 10; FR 10) on that lever resulted in a 5-s infusion of 0.1 $\mathrm{mg} / \mathrm{kg}$ sodium methohexital, followed by a 10 -s time-out during which all stimulus lights were extinguished and responding had no programmed consequence. During an infusion, the red lever light was extinguished and the center green light illuminated for the duration of the infusion. Experimental sessions were limited to $210 \mathrm{~min}$ or until a maximum of 200 injections were delivered. No monkey ever received 200 injections of methohexital. Two sessions were scheduled each day, separated by at least $4 \mathrm{~h}$. On approximately half of the baseline sessions, presented in an unsystematic order, the monkeys were exposed to response-contingent saline. When there was a clear and consistent differential response between saline and methohexital, doses of aminorex were substituted for one session. All conditions were similar to training sessions except the maximum number of injections of the test compound was 150/session. Each dose was tested twice in each monkey.

Aminorex and methohexital were dissolved in distilled water. Concentrations were appropriate for a $1.0-\mathrm{ml}$ injection.

\subsection{Discriminative stimulus effects in rhesus monkeys}

The subjects were two female and five male rhesus monkeys weighing between 6.5 and $12.1 \mathrm{~kg}$. All monkeys had extensive experience with the present drug discrimination procedure. They were housed individually in stainless steel cages in which water was continuously available. They were fed $100-150 \mathrm{~g}$ of monkey chow after each session and were given a chewable vitamin tablet 3 days/week. During experimental sessions each monkey was seated in a restraining chair (Plas Labs, Lansing, MI) and placed in a wooden cubicle $(175 \mathrm{~cm}$ high $\times 85 \mathrm{~cm}$ wide $\times 65 \mathrm{~cm}$ deep) containing two response levers mounted $100 \mathrm{~cm}$ above the floor. A 40-W white house light was mounted on the ceiling. The mon- 
key's feet were placed into shoes, the bottoms of which were fitted with brass plates which could deliver electric shocks. Programming and recording of experimental events were accomplished by an Aim 65 microprocessor located in an adjacent room.

The monkeys had been trained previously to discriminate $d$-amphetamine (AMPH: 7737, 7739, 8515) or pentobarbital (PB: 8106, 8236, 7976, 8814) from saline in a two-lever, discrete-trials shock avoidance procedure similar to the one described by Holtzman (1982). One hour after an intragastric infusion (via nasogastric tube) of the training drug $(0.56$ or $1.0 \mathrm{mg} / \mathrm{kg}$ AMPH or $10 \mathrm{mg} / \mathrm{kg} \mathrm{PB}$ ) or saline, the houselights and lever lights were illuminated (trial) and responding on one lever (correct lever) avoided electric shock (avoidance response) and extinguished the lights. Responding on the incorrect lever started a 2-s change-over delay during which correct lever responding had no consequence. If a correct lever response was not made within $5 \mathrm{~s}$ of onset of the lights, an electric shock ( 250 ms duration, $7 \mathrm{~mA}$ intensity) was delivered; if a correct response was made within $2 \mathrm{~s}$ after the first shock (escape response), the trial was terminated. Otherwise, a second shock was delivered and the trial ended automatically. Two consecutive trials in which a monkey failed to make an escape response automatically ended the session. Trials were separated by a 30 -s timeout. The session lasted 30 trials or $20 \mathrm{~min}$, whichever came first. The correct lever was determined by the infusion that was administered before the session. For three monkeys, the right lever was correct after drug infusion and the left lever was correct after saline infusions. This condition was reversed for the other four monkeys.

Monkeys were considered to be stable in the discrimination when more than $90 \%$ of the trials were avoidance trials and the first response in the session was appropriate to the injection for at least seven out of eight consecutive sessions. At this point, testing was begun with the training drugs and the test drug. Two 5-day sequences alternated drug, vehicle and test sessions so that the first test session was preceded by two training sessions, one with saline and one with drug pretreatment and the second test session of the sequence was preceded by either vehicle or drug pretreatment. In the event that the criterion for stimulus control was not met during the training sessions, the training sequence was continued. During test sessions, both levers were operational, i.e., shock could be avoided by responding on either lever. Because aminorex was evaluated blind without any dose-response information, initial test doses were done in an ascending order from $0.1 \mathrm{mg} / \mathrm{kg}$ to a dose that either resulted in at least $90 \%$ drugappropriate responding or increased response latency. When a dose was found that substituted for the training drug, that dose, at least one higher dose and one lower dose were tested again, in a random order. For those doses that were tested twice, one test was preceded by a drug training session and one by a saline training session.

A stock solution of AMPH (National Institute on Drug Abuse, Rockville, MD) was prepared in saline in a concentration of $5.0 \mathrm{mg} / \mathrm{ml}$. Sodium pentobarbital (Sigma Chemical Co., St. Louis, MO) was diluted with $0.9 \%$ saline to a final concentration of $40 \mathrm{mg} / \mathrm{ml}$, from a stock solution $(400 \mathrm{mg} / \mathrm{ml})$ with propylene glycol, $95 \%$ $\mathrm{EtOH}$, and sterile water (4:1:5). Aminorex was dissolved in saline in a concentration of $1.0 \mathrm{mg} / \mathrm{ml}(0.1 \mathrm{mg} / \mathrm{kg})$ or $10 \mathrm{mg} / \mathrm{ml}(0.3-3.0 \mathrm{mg} / \mathrm{kg})$. Doses were varied by varying the volume of the stock solution that was given. The stock solution of AMPH was prepared each week while PB and aminorex were prepared immediately before testing. All drugs were given intragastrically via nasogastric tube followed by a flush with 1-2 $\mathrm{ml}$ of saline to clear the tube.

The mean percentage of trials in test sessions that were completed on the drug lever is presented for each monkey. In addition, the average time between the onset of a trial and a lever press (average latency) was calculated for each test session.

\subsection{Effects in rodents}

CF-1 mice (Harlan Labs, Dublin, VA) weighing 25-35 $\mathrm{g}$ were housed in plastic cages with food and water available ad lib. Spontaneous locomotor activity was measured in mice using a single beam photocell (Autotron, Inc., Danville, IL) which bisected a plastic cage containing two mice. Movement of the mice disrupted the beam and a 'count' of activity was recorded. Following i.p. administration of druy to each mouse. activity was recorded at 5-15, 35-50,65-95 and $125-185 \mathrm{~min}$. Activity at a given dose is expressed as percent of control activity with concurrently-assayed, vehicle-treated mice serving as controls. Doses ranged between one that had little effect on locomotor activity to one that was lethal in one of six mice $(20 \mathrm{mg} / \mathrm{kg})$. Naive mice $(n=6)$ were used for each dose. The injection volume was $10 \mathrm{ml} / \mathrm{kg}$.

Male Sprague-Dawley rats $(n=4-6 /$ group; Harlan Labs, Dublin, VA), initially weighing 200-225 g, were used in the chronic infusion and substitution experiments. They were individually housed in stainless steel cages with food and water freely available. After acclimation to the housing conditions, they were surgically prepared with an intraperitoneal cannula (PE90 tubing) while under methoxyflurane anesthesia. Rats were then acclimated to the infusion system over 3 days during which they were infused with $0.9 \%$ saline. This was followed by the continuous infusion of either saline (control rats) or pentobarbital sodium for 12 consecutive days using an escalating dosing schedule. Dosing was initiated at $100 \mathrm{mg} / \mathrm{kg} / 24 \mathrm{~h}$ and was increased by 
$100 \mathrm{mg} / \mathrm{kg} / 24 \mathrm{~h}$ each day until excessive sedation was observed. At that point, the daily increment was decreased to $50 \mathrm{mg} / \mathrm{kg} /$ day (Yutrzenka et al., 1985). At the end of the infusion period most rats were receiving $\mathrm{PB}$ at a dose of $850-900 \mathrm{mg} / \mathrm{kg} / 24 \mathrm{~h}$. Body weight was monitored daily during the drug infusion period.

Following the final day of pentobarbital infusion, a 24-h substitution period began during which PBdependent rats were infused with either saline or aminorex. Aminorex was infused in doses of 40 or 80 $\mathrm{mg} / \mathrm{kg} /$ day. This was followed by a $24-\mathrm{h}$ drug withdrawal period during which all rats received saline. Every $2 \mathrm{~h}$ for the first $12 \mathrm{~h}$ and again at $24 \mathrm{~h}$ of each period, rats were assigned a withdrawal score based on the degree of expression of several behavioral responses and signs including: response to prodding with a blunt instrument, to a puff of air directed at the head and to handling as well as the assumption of a characteristic posture (Yutrzenka et al., 1989). In addition, body weight was determined at 0,8 and $24 \mathrm{~h}$ of each period. Scores were assigned by two observers who were blind to the drug treatment. Investigators were blind to the identity of the compounds until all data were collected and analyzed.

Aminorex and PB sodium were dissolved in distilled water made isotonic with sodium chloride. The daily dose was administered in a volume of $8.0 \mathrm{ml}$.

The statistical significance of the effects on locomotor activity was determined by unpaired Student's $t$-test. ED-50 values and $95 \%$ confidence intervals for the locomotor activity measure were also determined when appropriate by the method of Litchfield and Wilcoxon (1949). Withdrawal scores for each treatment group were compared to the control by use of the MannWhitney $U$-test. Alterations in body weight were tested for significance using Student's $t$-test.

\section{Results}

Monkeys self-administered between 75 and 150 injections of methohexital in baseline sessions (Fig. 2). When saline was available, responding declined to between 20 and 30 injections/session. Aminorex maintained selfadministration that was above saline levels, and slightly below methohexital levels, at least at one dose $(0.003-0.03 \mathrm{mg} / \mathrm{kg} /$ injection) in all monkeys. On average, the maximum number of injections were selfadministered at a dose of $0.01 \mathrm{mg} / \mathrm{kg} /$ injection.

Aminorex produced a dose-related increase in druglever responding in all three AMPH-trained monkeys (Fig. 3). In two of the monkeys, full substitution for AMPH occurred at $0.3 \mathrm{mg} / \mathrm{kg}$ aminorex, whereas full substitution was seen at $3.0 \mathrm{mg} / \mathrm{kg}$ in the third monkey. Aminorex engendered no drug lever responding in PBtrained monkeys and had no systematic effect on latency to respond in either group of monkeys (data not shown).

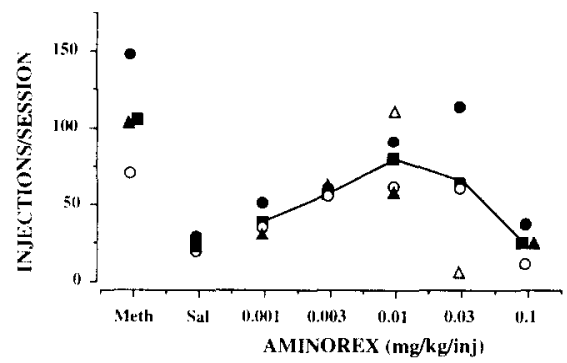

Fig. 2. Reinforcing effects of aminorex in thesus monkeys. The points shown above METH are the average number of injections taken of 0.1 $\mathrm{mg} / \mathrm{kg} /$ injection of sodium methohexital during the sessions just preceding each substitution of aminorex. The points above SAL represent similar data for saline availability. These averages are shown for the individual monkeys and the group as indicated by the legend. Points above aminorex doses are means of at least two observations for each monkey. $\square$, Mean;, $188 ; \mathrm{O}, \mathrm{RC} 245 ; \boldsymbol{\Lambda}, \mathrm{M} 1 ; \Delta, 699$.

Aminorex increased locomotor activity and this stimulant effect became statistically significant at 1.25 $\mathrm{mg} / \mathrm{kg}$. Stimulation was dose-related between 1.25 and $20 \mathrm{mg} / \mathrm{kg}$, but not markedly so (see Table 1). The highest dose tested $(20 \mathrm{mg} / \mathrm{kg})$ was lethal in one of six mice. When rats were infused only with saline (substitution and withdrawal), mean withdrawal scores were less than 0.5 for the entire 48-h scoring period (Fig. 4, SAL+SAL). When saline was substituted for $P B$ (PB+SAL), mean withdrawal score peaked at about 1.7 at $8 \mathrm{~h}$ and gradually declined thereafter. When 40 or 80 $\mathrm{mg} / \mathrm{kg}$ aminorex was infused into PB-dependent rats $\mathrm{PB}+$ aminorex, the overt signs of withdrawal were markedly increased relative to $\mathrm{PB}+\mathrm{SAL}$ beginning $24 \mathrm{~h}$ after the infusion and tremor was noted in many of the rats. Moreover, the effects were greater than those of aminorex alone in the $80 \mathrm{mg} / \mathrm{kg}$ group at 24 and $26 \mathrm{~h}$. The exacerbation of withdrawal signs was dose-related, and the elevation of signs persisted for at least $32 \mathrm{~h}$

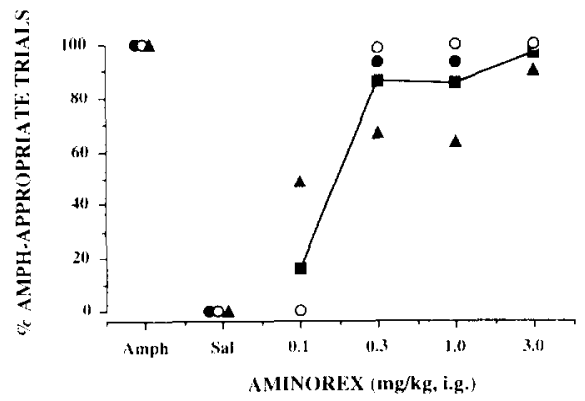

Fig. 3. Discriminative stimulus effects of aminorex in rhesus monkeys trained to discriminate AMPH from saline. Each point represents the percentage of trials in a test session that were completed on the drug lever. Generally, each point is the mean of two determinations and this is always the case for points that are above $80 \%$. The points above AMPH and SAL are from test sessions with the training dose of AMPH or SAL, respectively. $\mathbf{Q}$ Mean; $\bullet, 7739 ; 0,8515 ; \boldsymbol{\Delta}, 8906$. 


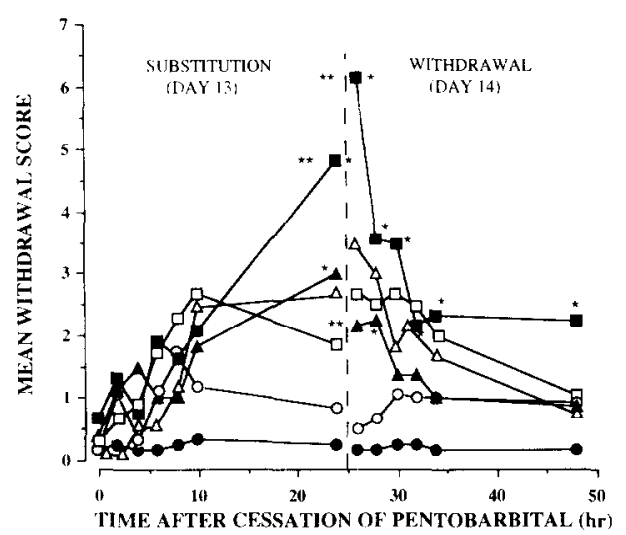

Fig. 4. Mean withdrawal scores of control rats (SAL+SAL) and PBdependent rats during substitution of aminorex or saline (Substitution, Day 13) and during substitution of saline (Withdrawal, Day 14). Each point represents the mean score from four to six rats. ${ }^{*}$, Different from PB + Sal, $P<0.05 ;{ }^{* *}$, Different from corresponding SAL + aminorex, $P<0.05$. - SAL + SAL; $\triangle$, SAL + 40 aminorex: $\square$, $\mathrm{SAL}+80$ aminorex; $\mathrm{O}, \mathrm{PB}+\mathrm{SAL} ; \mathbf{A}, \mathrm{PB}+$ aminorex; $\square, \mathrm{PB}+80$ aminorex.

following cessation of the higher dose. When saline replaced PB, rats lost about $10 \%$ of their body weights over the first $24 \mathrm{~h}$ (Fig. 5). This was also significantly increased by substitution of aminorex although there was no difference in the effect of the two doses.

\section{Discussion}

Aminorex functioned as a positive reinforcer in all four rhesus monkeys that were tested. This finding is similar to previous results with the aminorex derivative 4-methylaminorex (Mansbach et al., 1990) and suggests that aminorex has abuse liability in humans. In addition, aminorex produced dose-related AMPH-like discriminative stimulus effects, fully substituting for amphetamine in all monkeys. This result is consistent with a previous report by Glennon et al. (1990) of AMPH-

Table 1

Effects of aminorex on spontaneous locomotor activity of mice ${ }^{a}$

\begin{tabular}{lllll}
\hline Dose $^{b}$ & \multicolumn{4}{l}{ Time after injection (min) } \\
\cline { 2 - 5 } & $5-15$ & $35-50$ & $65-95$ & $125-185$ \\
\hline 0.62 & 149 & 124 & 196 & 234 \\
1.2 & 180 & $238^{*}$ & $488^{*}$ & 82 \\
2.5 & $270^{*}$ & 183 & $674^{*}$ & 152 \\
5.0 & $244^{*}$ & $379^{*}$ & 180 & 176 \\
10 & $303^{*}$ & $460^{*}$ & $1074^{*}$ & \\
20 & 95 & 132 & $562^{*}$ & $3010^{*}$ \\
\hline
\end{tabular}

${ }^{a}$ Values are expressed as the percentage of activity of concurrently tested vehicle-treated control mice.

${ }^{b}$ Doses are $\mathrm{mg} / \mathrm{kg}$, i.p.

*Different from concomitant control at $P<0.05$.

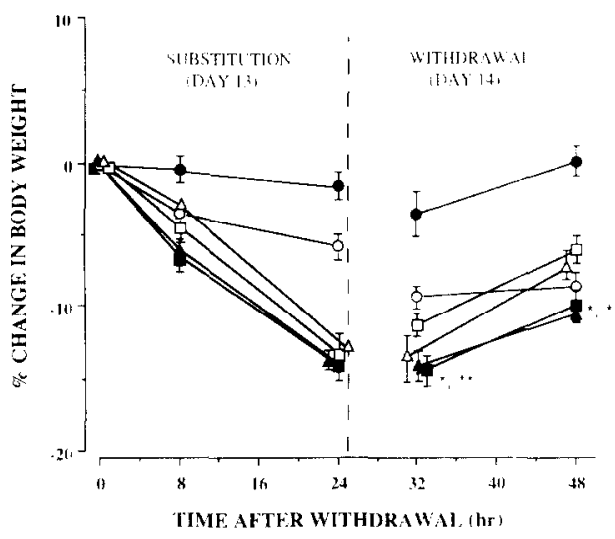

Fig. 5. Change in body weight of control rats (SAL+SAL) and PBdependent rats during substitution of aminorex or saline (Substitution, Day 13) and during substitution of saline (Withdrawal, Day 14). Each point represents mean change in body weight $( \pm$ SEM) from four to six rats. ${ }^{*}$, Different from $\mathrm{PB}+\mathrm{SAL}, P<0.05 ;{ }^{* *}$. Different from corresponding $\mathrm{SAL}+$ aminorex, $P<0.05 . \quad-\mathrm{SAL}+\mathrm{SAL} ; 0$, PB + SAL; $\triangle$, SAL +40 aminorex: $\square, \mathrm{SAL}+80$ aminoex $\triangle \mathrm{AB}+40$ aminorex: $\mathbf{D B}+80$ aminorex.

like discriminative stimulus effects in rats. Since drug discrimination procedures predict the subjective effects of drugs in humans, this finding predicts AMPH-like subjective effects of aminorex in humans. Additionally, aminorex stimulated locomotor activity in mice to an extent greater than that seen with cocaine but less than that seen with AMPH (unpublished data) and exacerbated PB withdrawal in the same way as mazindol (Yutrzenka et al., 1990). Taken together, our results suggest that aminorex is similar to traditional psychomotor stimulants and that aminorex has abuse liability of the AMPH type.

\section{Acknowledgements}

This research was supported by NIDA Grant DA05951 and the College on Problems of Drug Dependence. The animals used in this study were maintained in accordance with the USPHS Guide for Care and Use of Laboratory Animals and all procedures were approved by the appropriate Institutional Animal Care and Use Committees.

\section{References}

Costa E, Naimzada KM, Revuelta, A. Effect of phenmetrazine. aminorex and $( \pm) p$-chloroamphetamine on the motor activity and turnover rate of brain catecholamines. Br J Pharmacol 1971: 43: 570-579.

Coughenour LL, McLean JR. A new device for the rapid measurement of impaired motor function in mice. Pharmacol Biochem Behav 1977; 6: 351-353

Deneau GA, Yanagita T, Seevers MH. Self-administration of psychoactive substances by the monkey. A measure of psychological dependence. Psychopharmacologia 1969, 16:30-48 
Follath F, Burkart F, Schweizer W. Drug-induced pulmonary hypertension. Br Med J 1971; I: 265-266.

Fristrom S, Airaksinen MM, Halmekoski J. Release of platelet 5hydroxytryptamine by some anorexic and other sympathomimetics and their acetyl derivatives. Acta Pharmacol Toxicol 1977; 41: 218-224.

Glennon RA, Misenheimer B. Stimulus properties of a new designer drug: 4-Methylaminorex ("U4Euh"). Pharmacol Biochem Behav 1990; 35: 517-521.

Hadler AJ. Studies of aminorex, a new anorexigenic. J Clin Pharmacol 1967; 7: 296-302.

Hadler AJ. Further studies of aminorex, a new anorexigenic agent. Clin Ther Res 1970; 12: 639-644.

Holtzman SG. Phencyclidine-like discriminative stimulus properties of opioids in the squirrel monkey. Psychopharmacology 1982; 77 : 295-300.

Litchfield JT, Wilcoxon F. A simplified method of evaluating doseeffect experiments. J Pharmacol Exp Ther 1949; 96: 99-113.

Mansbach RS, Sannerud CA, Griffiths RR, Balster RL, Harris LS. Intravenous self-administration of 4-methylaminorex in primates. Drug Alcohol Depend 1990; 26: 137-144.
Mlczoch J, Probst P, Szeless S. Primary pulmonary hypertension: Foliow-up of patients with and without anorectic drug intake. Cor Vasa 1980; 22: 251-257.

Roszkowski AP, Kelley NM. A rapid method for assessing drug inhibition of feeding behavior. J Pharmacol Exp Ther 1963; 140: 367-374.

Wood LC, Owen JA. Clinical evaluation of a new anorexigenic drug, aminoxaphen, in obese diabetics. J New Drugs 1965; 5: 181-185.

Young RA. Aminorex produces stimulus effects similar to amphetamine and unlike those of fenfluramine. Pharmacol Biochem Behav 1992; 42: 175-178.

Yutrzenka GJ, Patrick GA, Rosenberger W. Continuous intraperitoneal infusion of pentobarbital: a model of barbiturate dependence in the rat. J Pharmacol Exp Ther 1985; 232: 111-118.

Yutrzenka GJ, Patrick GA, Rosenberger W. Substitution of temazepam and midazolam in pentobarbital-dependent rats. Physiol Behav 1989; 46: 55-60.

Yutrzenka GJ, Patrick GA, Rosenberger, W. Substitution of psychoactive drugs in pentobarbital-dependent rats. Drug Alcohol Depend 1990; 26: 9-17. 